\section{Jobb for personer med psykiske plager}

Angelika Schafft

Å få seg en jobb

Arbeidsrettet rehabilitering ved psykiske helseproblemer. 128 s. Oslo:

Kommuneforlaget, 2010. Pris NOK 328

ISBN 978-82-446-2012-3

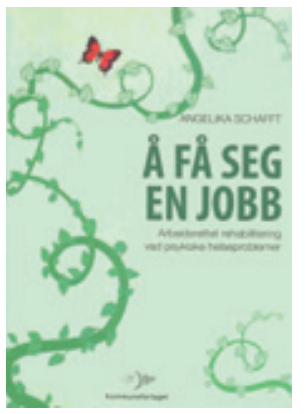

Boken er basert på gjennomgang av nyere skandinavisk faglitteratur om arbeidsintegrering og psykiske lidelser og kunnskap fra prosjekter i Norge. Den er aktuell for helsearbeidere i psykisk helsevern, ansatte i velferds-

apparatet og offentlig forvaltning, pasienter og pårørende og kanskje spesielt for politikere som må prioritere hvilke gode tiltak og prosjekter som skal få offentlig støtte. Forfatteren er utdannet cand.polit. og er seniorforsker ved Arbeidsforskningsinstituttet i Oslo.

Boken er inndelt i seks kapitler med korte avsnitt og med en god oppsummering etter hvert kapittel. Den er velskrevet og lettlest til tross for at den har svært nøktern layout og er helt uten illustrasjoner. Gjennomgang av de mange igangsatte tiltak og prosjekter fra forskjellige etater, og i hvilken grad disse er koordinert, har fătt bred plass. I de to siste kapitlene er det oppsummert hvorfor noen tiltak virker godt og noen dårlig og hva som er utfordringene videre for å øke arbeidsdeltakelsen hos personer med psykiske lidelser. Til tross for mange ulike tiltak er antall «yrkeshemmede» med en psykisk diagnose tredoblet fra 1994 til 2005 - de fleste av disse har en såkalt «lettere» psykisk lidelse. Mange har en uførhet som er «situasjonsbetinget», dvs. at en person kan gjøre en god innsats på en trygg og god arbeidsplass, mens vedkommende $i$ en annen jobb ikke fungerer i det hele tatt. Temaet er således svært viktig, både for den enkelte pasient og for samfunnet.

Forfatteren er kritisk til den tradisjonelle «trappetrinnstenkingen», der det psykiske helsevern først skal gjøre pasienten frisk(ere) og deretter skal andre instanser komme inn og hjelpe til med å skaffe arbeid og bolig m.m. Arbeidsintegrering i tilrettelagt arbeid der behandling og arbeidstrening går hånd i hånd, såkalt «supported employment», ser ut til å gi bedre resultater. Tett individuell oppfølging er viktig for å etablere og fastholde et jobbforhold - god personkjemi mellom jobbkonsulent eller «los» er avgjørende. Det er også viktig at tiltakene ikke vanskeliggjøres av byråkratiske hindre mellom stat, kommune og helsevesen. De må heller ikke være for kortvarige. Ofte kjenner de ulike instansene ikke godt nok til hverandres oppgaver og regler for bistand. Og det hjelper lite at «arrangørene» opplever prosjekter som «vellykkede» hvis brukerne står på stedet hvil når prosjektperioden er over! Målet må være ordinært «ordentlig» arbeid (enten heltid eller deltid, eventuelt med skikkelig støtte til arbeidsgiver) og ikke bare at personene skal ha «noe å pusle med».

Boken anbefales til alle som er interessert $\mathrm{i}$ å bedre den lave arbeidsdeltakelsen hos personer med psykiske lidelser og spesielt til dem som skal planlegge og bevilge penger til videre tiltak.

\section{Gunnar Mouland}

Legegruppen Grandgården Arendal

\section{Muskelfysiologi og kronisk smerte}

Jan Spiechowicz, Tine von Hanno

\section{Muskler i kronisk smerte}

Muskelfysiologi anvendt i funksjonsrestituerende behandling av kronisk smerte. 528 s, ill. Oslo: Kolofon forlag, 2009. Pris NOK 695 ISBN 978-82-300-0636-8

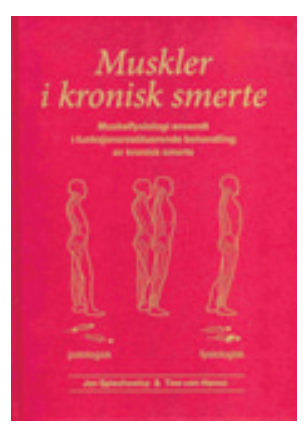

Målgruppen er alle som behandler pasienter med kronisk smerte med opphav i bevegelsesapparatet. Innledningsvis gis en omfattende liste med definisjoner og ordforklaringer. Deretter følger en svært leseverdig prolog om kronisk smerte. Her reflekterer forfatteren rundt smertens biologiske formål, hvordan smerte kan betraktes både ut fra en biomedisinsk og en biopsykososial sykdomsmodell, hvorvidt kronisk smerte er et syndrom eller ulike sykdommer og tanker rundt medikalisering av kroniske smertetilstander. Disse innledende betraktningene leder frem til refleksjoner rundt hvorfor det er så vanskelig å behandle kronisk smerte effektivt og refleksjoner rundt valget mellom symptomrettet versus årsaksrettet behandling.

En mengde figurer illustrerer poengene $i$ teksten godt og er nyttige for å forstå mange av poengene om biomekanikk og en del av øvelsene som anbefales. Hvert avsnitt avsluttes med en referanseliste med en del nøkkelreferanser. Hvor mange referanser som er angitt, varierer i de ulike avsnitt og kapitler. Det er derfor vanskelig for leseren å skille mellom innhold som har høy og lav grad av dokumentasjon. Hva er forskningsbasert kunnskap og hva er erfaring fra mange år med klinisk arbeid? På slutten av flere av kapitlene er det også en oversikt over bøker som anbefales som «basislitteratur» knyttet til kapitlets tema. I tillegg er det 22 kasuistikker som illustrerer utredning og behandling av ulike smertetilstander.

Det første av de seks hovedkapitlene handler om samspillet mellom anatomi og muskelfysiologi. Kapittel 2 er en gjennomgang av konsekvenser av å betrakte smerte ut fra Loesers teoretiske smertemodell, som er basert på at smerte består at fire sfærer: nocisepsjon, smerte, lidelse og smerteatferd. Videre følger kapitler om funksjonsrestituerende behandling, ikke-invasiv funksjonsrestituerende behandling gjennom aktiv trening og til slutt kapitler om reversering av myofascielle smertesyndromer $\mathrm{i}$ henholdsvis ramus posterior-gebetet og ramus anterior-gebetet. Mens de siste kapitlene først og fremst er relevante for helsepersonell som har det meste av sitt arbeid knyttet til pasienter med kronisk smerte i bevegelsesapparatet, er de første kapitlene relevante for en langt videre leserkrets.

Gjennom hele boken fremholdes viktigheten av en nøyaktig og målrettet klinisk undersøkelse for best mulig diagnostikk. Videre fremheves viktigheten av at funnene fra slik grundig klinisk undersøkelse brukes til målrettet funksjonsrestituerende trening. Altså er boken preget av den biomedisinske tilnærmingen. Da er det bare å håpe at leseren etter å ha lest hele boken, husker betraktningene i prologen: Langvarige smertetilstander bør ikke alene fortolkes ut fra en biomedisinsk modell. Behandleren må kunne veksle mellom den biomedisinske og den biopsykososiale sykdomsmodellen. Min største innvendig er at teksten er forholdsvis lang og tung å lese. 